\title{
Sediment transport and deposition during extreme sea storm events at the Salerno Bay (Tyrrhenian Sea): comparison of field data with numerical model results
}

\author{
F. Budillon ${ }^{1}$, D. Vicinanza ${ }^{2}$, V. Ferrante ${ }^{2}$, and M. Iorio ${ }^{1}$ \\ ${ }^{1}$ Istituto per l'Ambiente Marino Costiero, C.N.R., Calata Porta di Massa, 80 - 80133 Napoli, Italy \\ ${ }^{2}$ Dipartimento di Ingegneria Civile, Seconda Universita' di Napoli, Aversa, Italy
}

Received: 16 May 2006 - Revised: 4 September 2006 - Accepted: 4 September 2006 - Published: 25 September 2006

\begin{abstract}
Seismic stratigraphy and core litho-stratigraphy in the Salerno Bay inner shelf (Southern Tyrrhenian Sea) reveal significant storm deposition episodes over the last $1 \mathrm{ky}$. Three major events are preserved as decimetre thick silt/sand layers bounded at their base by erosional surfaces and sealed in the muddy marine sequences between 25 and $60 \mathrm{~m}$ of depth. Geochronology and chrono-stratigraphy on core sediment point towards a recurrence of major sea storms between 0.1 and $0.3 \mathrm{ky}$ and put the last significant event in the 19th century, when no local meteorological time series is available. A modelling of extreme sea-storms with a return period of about $0.1 \mathrm{ky}$ is here proposed based on historical hindcast and aims at explaining the occurrence of such unusual deep and thick sand deposits in the northern sector of the bay. Results highlight the vulnerability of the northern coast of the Salerno Bay to the south western sea storms which can drive waves up to about $8 \mathrm{~m}$ high and wave period of about $13 \mathrm{~s}$. With these conditions an intense combined flow current is formed and might account for winnowing fine sand down to the depth of $40 \mathrm{~m}$ at least. The numerical model thus confirms a possible sand transport in the bottom boundary layer due to wave-current interaction and could corroborate the interpretation of the most recent sand layers, included in the cores, as being generated under extreme sea storm conditions.
\end{abstract}

\section{Introduction}

\subsection{Sea storm event beds}

Sea storm current-waves interaction is recognized as being one of the most effective dynamics of sediment resuspension and deposition, able to drive sand outside the surf zone.

Correspondence to: F. Budillon

(francesca.budillon@iamc.cnr.it)
Winter storm action induces sediment resuspension from the seabed and flows in the bottom boundary layer (bbl) and might result in the formation of structured sandy layers lying on erosive surfaces in the stratigraphic record of mid-latitude shelves (Dott and Bourgeois, 1982; Duke, 1985; Greenwood and Sherman, 1986; Niedoroda et al., 1989; Duke et al., 1991; Myrow and Southard, 1996). The occurrence of sandy layers in the stratigraphic record of lakes and coastal areas is thus considered a proxy for past storminess (Andrade et al., 2004). Their formation and preservation is not common since it might depend on many factors, such as the disposability of sand from the coastal system, the burial rate, the bioturbation, the possible sand winnowing due to subsequent storm recurrence (Wheatcroft and Drake, 2003; Keen et al., 2004; Dawson et al., 2004a). Only major events are normally retained onto the middle shelves, which can disclose sand layers up to $10 \mathrm{~cm}$ thick (Morton, 1981; Snedden and Nummendal, 1991).

In the marine environment the detection of tempestite layers is achieved mainly on the base of cores analysis, thus with a restricted point of view (Keen et al., 2004; Budillon et al., 2005a): typical structures as "hummocky cross stratification" and scours, pertaining to storm deposition and providing information about flow directions and hydrodynamic regimes, are not recognisable. In that cases many aspects of storm deposition remain unknown, because neither current velocities at the seabed nor wind-wave parameters are measurable, as for storms occurring before the 20th century. The case study of the Salerno Bay (Fig. 1) is here proposed to attempt a genetic link between well sorted sandy layers disclosed in the shelf stratigraphic record and hypothetic sea storms. Three event beds, tentatively related to major sea storms that likely impacted the area in the last $1 \mathrm{kyr}$, are considered. Nevertheless being those deposits locally very thick and deep more evidences are needed to confirm this interpretation. The uppermost two sandy layers (T1 and T2) were interpreted as being generated most likely by two major sea-storms that occurred

Published by Copernicus GmbH on behalf of the European Geosciences Union. 


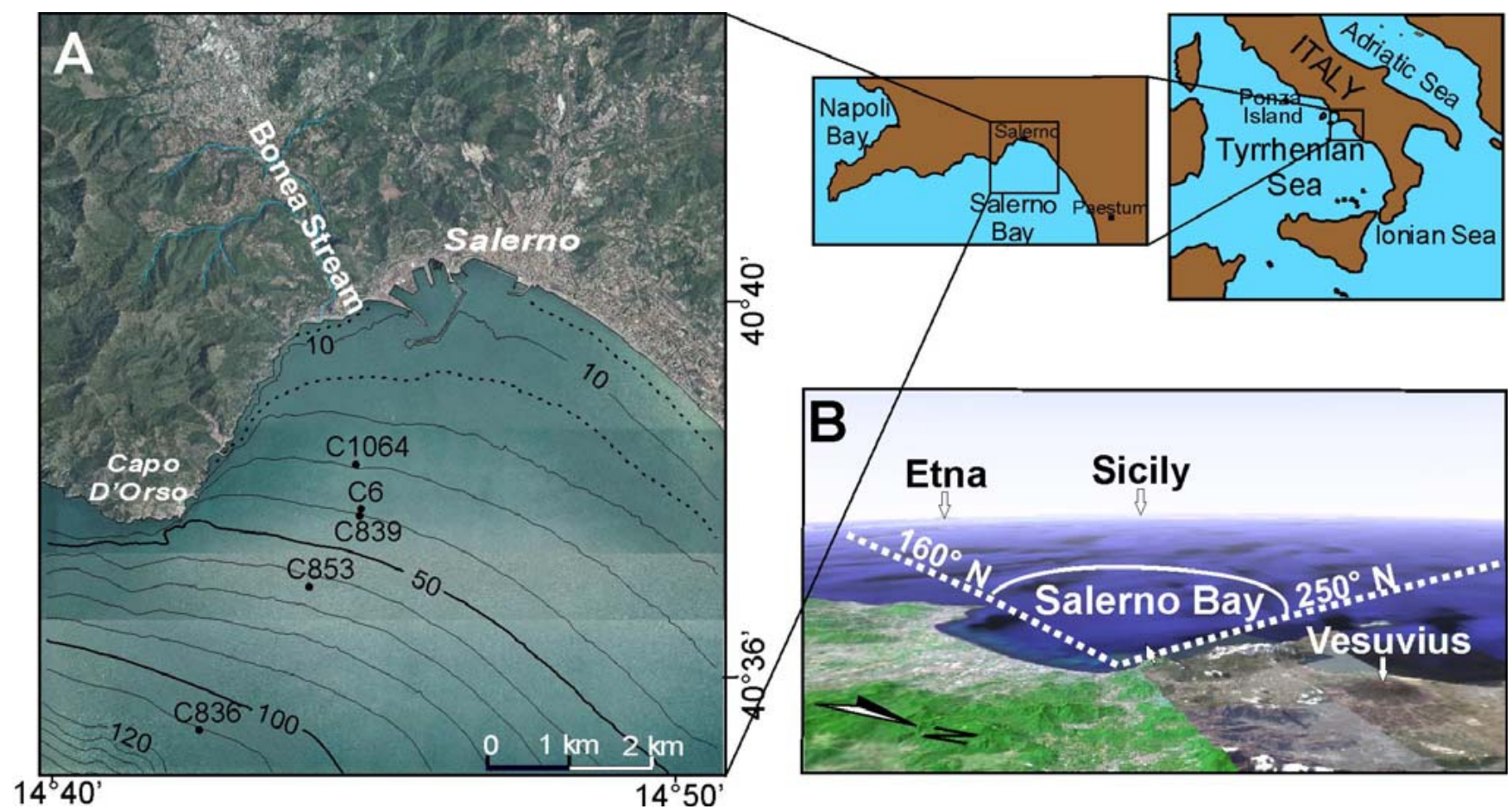

Fig. 1. (A) The Salerno Bay shelf; present day bathymetry in metres and position of studied cores; (B) Wave exposure of the northern coast of the bay.

Images are from google.com archives; bathymetric contour from Istituto per l'Ambiente Marino Costiero - (CNR) data set.

in 1544 and 1879 A.D., respectively, while the oldest sand layer (T3) dated to the 11th century (Budillon et al., 2005a, $2005 \mathrm{~b}$ ), with a uncertainness of about $0.15 \mathrm{ky}$ (Sagnotti et al., 2005).

It is interesting to mention that, if the chronologic framework proposed in Budillon et al. (2005a) is correct, the most recent two event beds ( $\mathrm{T} 1$ and $\mathrm{T} 2$ ) fall in the climatic cooling phase known as Little Ice Age - L.I.A. (Ingram et al., 1978; Bradley and Jones, 1993) occurred from the middle of the 15 th century to the 19 th century, with a likely higher intensity of exceptional winter storms (Lamb, 1979; Dawson et al., 2004). The oldest event bed (T3), might be coeval to the definitive desertion of the ancient town Paestum, close to the studied area, due to alluvial cover and drowning of the area (Violante et al., 2001).

\subsection{Sediment transport outside the surf zone}

Coastal scientist usually consider waves and their associated currents, acting from the breaking point to the beaches, as the most important cause of sediment transport in shallow water.

Outside the surf zone to approximately $50 \mathrm{~m}$ of depth the importance of waves and currents on sediment transport processes is not easily traceable. The material carried offshore during major sea storms is deposited on the inner shelf (Ellis, 1978) at depths from which it cannot return to the surf zone under normal wave conditions. The near-bottom hydrodynamics in this zone can be determined by the nonlinear interaction of waves and slowly varying currents. This interaction between flows of different time scales results in a nested wave-current bottom boundary layer (bbl). Measurements on bbl at a depth of $50 \mathrm{~m}$ offshore the Eel River (USA), using the GEOPROBE tripod, showed that the strongest near-bottom flows (combined wave and current speeds of over $1 \mathrm{~m} / \mathrm{s}$ ) and highest sediment concentrations (exceeding $2 \mathrm{~g} / \mathrm{l}$ at $1.2 \mathrm{~m}$ above the seabed) occurred during two moderate storms (Cacchione et al., 1999). Near-bed currents and suspended sediment flux were monitored also on the Palos Verdes shelf offshore California with a bottom tripod at a $63-\mathrm{m}$-deep site and values of $0.4 \mathrm{~cm} \mathrm{~s}^{-1}$ and $90 \mathrm{~kg} \mathrm{~m}^{-1} \mathrm{~h}^{-1}$ were measured, respectively (Wiberg et al., 2002).

A simple model to obtain an analytical expression for combined wave-current bbl features and associated sediment transport was proposed by Grant and Madsen (1986). A review of alternative models, employing more sophisticated turbulence closure schemes is given in Madsen and Wikramanayake (1991).

This study aims at reconstructing the dynamics of deposition of the sand layers found in the cores and at evaluating the response of the Salerno coastal system to extreme sea storm events. In particular, a link between the deposition of sandy 
layer $\mathrm{T} 1$ disclosed by the cores, and sea storm combined flows in offshore is attempted, by using numerical models. Coastal circulation and sediment transport models are employed to simulate respectively hydrodynamic regimes and wave-current bbl at core sites C1064 and C6, in order to verify the possibility that sand resuspension and motion may occur, even at depth, in offshore.

\section{Study area}

\subsection{Geological setting}

The northern sector of the Salerno Bay is oriented to the southwest and is bounded by rocky coastal cliffs to the west and by a coarse sandy shore to the east. Well sorted sand spreads all along the northern coast of the bay and forms the submerged beach wedge down to $15 \mathrm{~m}$ of depth (Cocco et al., 1992); below it gives way to less sorted muddy fine sand from which, at places portions of coarser deposits related to riverine hyperpycnal flows crop out (Violante and Budillon, 2004). The bay encloses a continental shelf of about $9 \mathrm{~km}$ wide, bounded seawards by a sharp shelf break at $120 \mathrm{~m}$ of depth (Fig. 1a).

Shelf gradient ranging between $0.6^{\circ}$ and $1^{\circ}$ depends on the geometry of the Late Holocene marine wedge, which has been aggrading at different rates from the coast to the sea. Values of sedimentation rate on the outer shelf are quite high, ranging between $40 \mathrm{~cm} \mathrm{ky}^{-1}$, over the 7-2 ky time span and about $100 \mathrm{~cm} \mathrm{ky}^{-1}$ over the last $2 \mathrm{ky}$ (Iorio et al., 2004). About $2 \mathrm{~m}$ of marine sediment overlie the reflector generated by the pumice deposit of the 79 A.D. Vesuvius eruption onto the mid-shelf (Conforti, 2003).

In previous studies three tempestite layers were identified in cores and tentatively dated by merging different information coming from tephrastratigraphy, ${ }^{137} \mathrm{Cs}$ and ${ }^{210} \mathrm{~Pb}$ inventories, paleomagnetic curves (Budillon et al., 2005b). They appear as sharp based decimetre thick massive or normally graded fine sand/silt layers, thinning seawards (Fig. 2). Textures point to a good sorting of grains with unimodal distribution of classes and suggest winnowing and progressive sorting of grains (Budillon et al., 2005a).

In the time span encompassing the settlement of tempestite deposits herein examined, no relevant sea level variations occurred $(0.4 \pm 0.08 \mathrm{~m}$ below present day sea level, Antonioli et al., 2002), while a general normal progradation of the western shoreline of about one hundred metres is reported (Cocco et al., 1992), together with variable phases of progradation and retreat of ephemeral deltas at the river mouth of the Bonea Stream (Esposito et al., 2004; Budillon et al., 2005b). The rocky coastal cliffs, on the contrary, were stable as revealed by first historical nautical maps based on modern triangulation principles (Rizzi Zannoni, 1792).
Table 1. Wave heights and periods for different return period.

\begin{tabular}{lllll}
\hline $\mathrm{T}_{r}$ (year) & 10 & 30 & 50 & 100 \\
\hline $\mathrm{H}_{S}(\mathrm{~m})$ & 6.53 & 7.36 & 7.82 & 8.02 \\
$\mathrm{~T}_{S}(\mathrm{~s})$ & 9.87 & 11.25 & 11.95 & 13.21 \\
\hline
\end{tabular}

\subsection{Deepwater wave hindcast for sea storm events}

The approach adopted in the following wave climate analysis was to hypothesize that the past wave regime was similar to the actual one. As mentioned above, this assumption is not fairly true, since Southern Italy as well recorded the LIA over the 15th and the 19th centuries (Silenzi et al., 2004). However this approach might only lead to an underestimation of the frequency and the intensity of sea storms with respect to the real climatic conditions ensued. Under this assumption the probability distribution of major storms events was evaluated. The Salerno Bay is exposed to waves coming from $160^{\circ} \mathrm{N}$ and $250^{\circ} \mathrm{N}$ (Fig. 1b). Wave data records were supplied by the Italian Sea Wave Measurement Network, which has operated since July 1989 (Rete Ondametrica Nazionale, RON). Three-hourly data set, provided by the wave buoy offshore Ponza Island (Tyrrhenian Sea) which included significant spectral wave height $\left(\mathrm{H}_{s}\right)$, peak period $\left(\mathrm{T}_{s}\right)$, and wave direction (DD) were analyzed. The extreme waves statistical analysis was carried out using the Peak Over Threshold method, according to the indications of Goda (1998). In order to take in account the difference between the site of measurement and the site object of this study, the offshore waves were transposed from Ponza Island to Salerno Bay at $115 \mathrm{~m}$ depth $(\mathrm{h} / \mathrm{L} \approx 0.5)$ isobaths using the following relationships between wave height and fetches:

$\frac{H_{m o}^{\mathrm{P}}}{H_{m o}^{\mathrm{O}}}=\left|\frac{F^{\mathrm{P}}}{F^{\mathrm{O}}}\right|^{\frac{1}{2}} \quad \frac{T_{m o}^{\mathrm{P}}}{T_{m o}^{\mathrm{O}}}=\left|\frac{F^{\mathrm{P}}}{F^{\mathrm{O}}}\right|^{\frac{1}{3}}$

Assuming $\mathrm{O}$ and $\mathrm{P}$ apexes, respectively as the values relative to the measured and to the transposition sites, and having established the mean direction of the wind, which the effective fetches are related to, the above mentioned equations permit to obtain the required correspondence between wave heights and periods relative to sites $\mathrm{O}$ and $\mathrm{P}$.

To estimate the direction of extreme wave events a threshold of three and six metres wave height was considered. Results shown in Fig. 3 emphasize that the direction coming from $230^{\circ} \mathrm{N}$ contains the greatest number of storm generating extreme events.

The estimated return values $\mathrm{H}_{s, T r}$ and $\mathrm{T}_{s, T r}$, from $230^{\circ} \mathrm{N}$, are reported in Table 1.

The wave period is evaluated using the Grancini et al. (1980) formula significant for the Southern Tyrrhenian Sea:

$T_{s}=4.082 \cdot H_{s}^{0.513}$ 

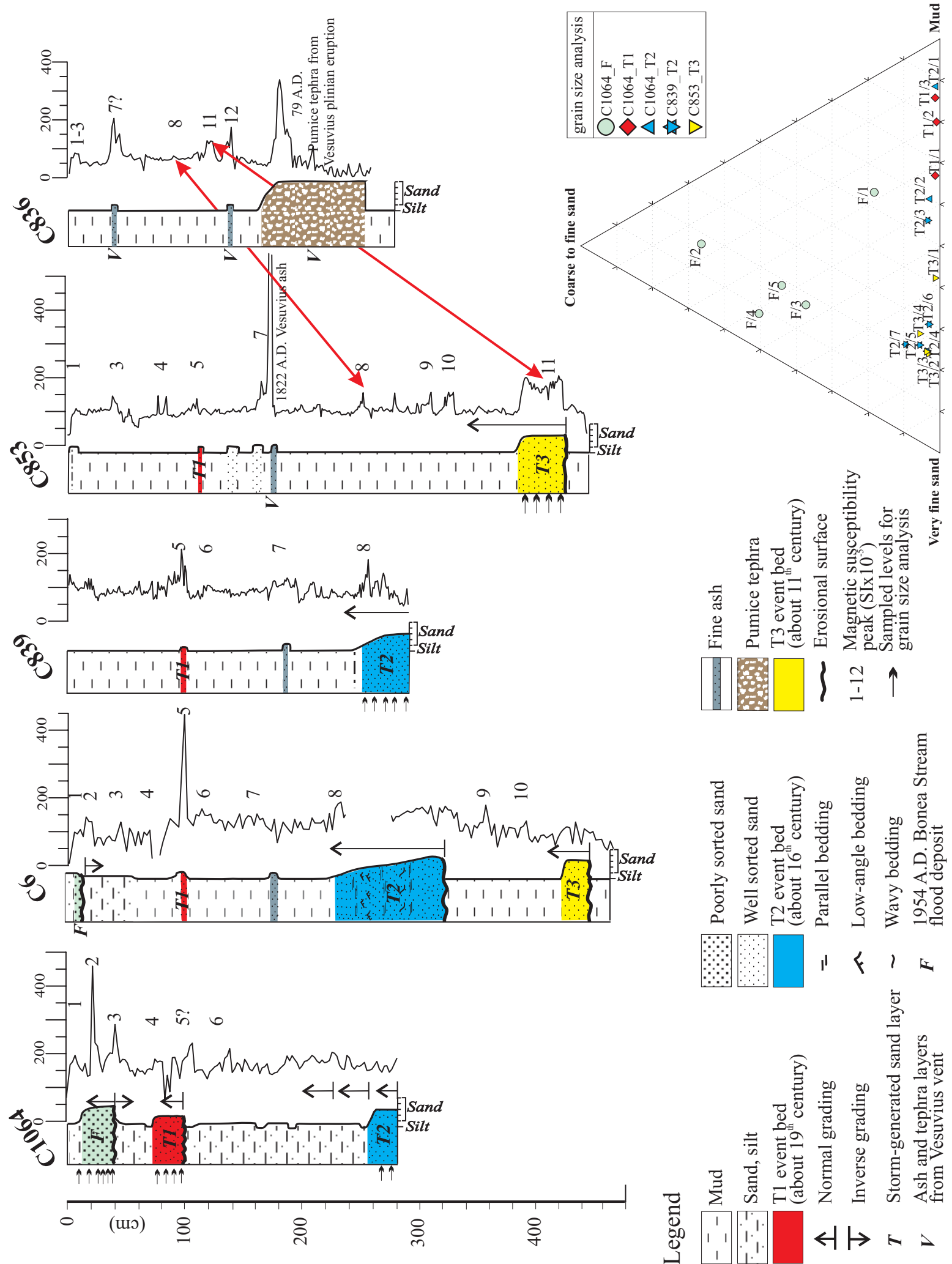

Fig. 2. Cores stratigraphy and grain size analysis of sand layers (from Budillon et al., 2005a, modified). T1, T2 and T3 layers were interpreted as being related to sea storm deposition; their age model, respectively 19th, 16th and 11th century, is attempted in Budillon et al. (2005a, b). 


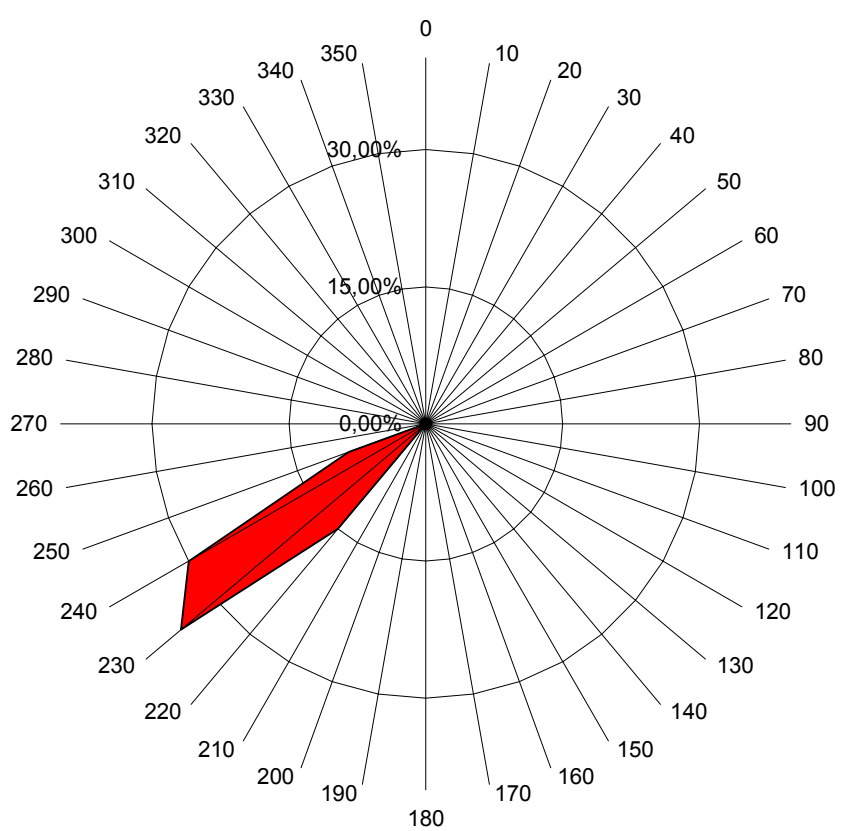

$\mathrm{Hs}>6 \mathrm{~m}$

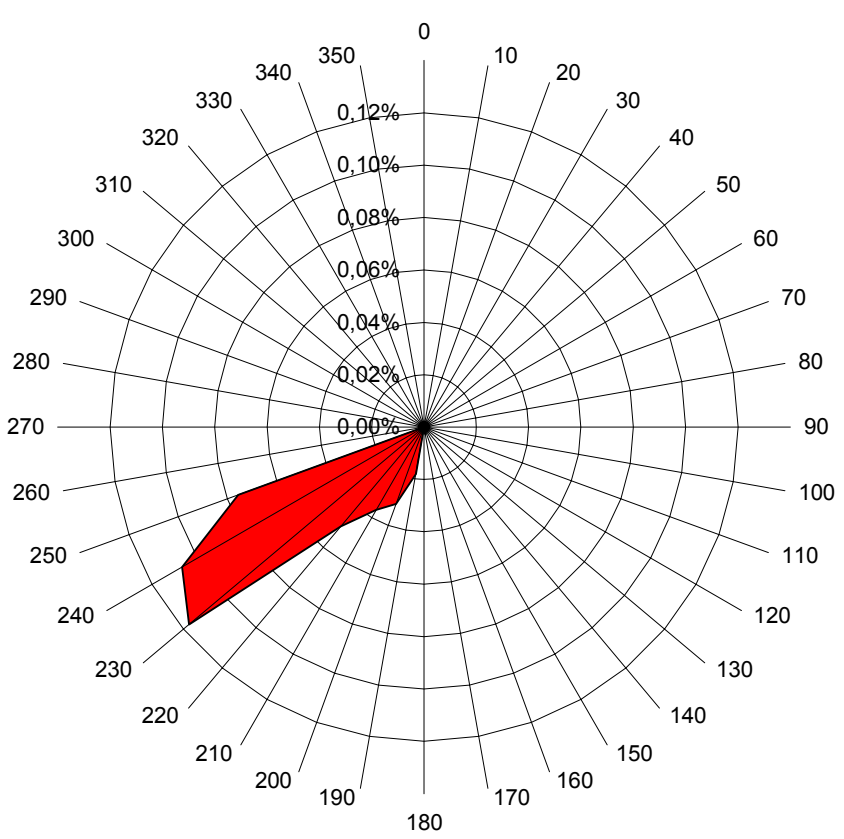

$\mathrm{Hs}>3 \mathrm{~m}$

Fig. 3. Polar diagram of wave height percentage over a defined threshold of 3 and $6 \mathrm{~m}$.

In this study all the simulations are performed considering the most extreme event achievable. The maximum wave height at site, generable compatibly with the maximum fetch in the wind wave generation area, is $8 \mathrm{~m}$. This value corresponds to a return period event of $0.1 \mathrm{ky}$ (Table 1).

2.3 Time recurrence of extreme sea storms from cores stratigraphy

Stratigraphic evidences from cores point to three major sea storms occurring over a $1 \mathrm{ky}$ time span (Budillon et al., 2005a). These deposits were related to particularly intense sea storms since their thickness (up to $80 \mathrm{~cm}$ in T2, Fig. 2) and horizontal distribution is not common. However, taking into account that deposition of tempestites can be discontinuous in space, and their preservation is not straightforward (i.e. others events could be not represented in the stratigraphic record because subsequently removed), a shorter, more realistic recurrence time of extreme sea storm events should be considered. Above the most recent sand layer (T1 peak 5, Fig. 2), the hyperpycnal deposits of 1954 A.D. Bonea Stream flood event is present (unit F in core 1064 and C6) and results un-winnowed (Budillon et al., 2005a, b; Violante and Budillon, 2004). Thus, the stratigraphic context allows to establish that the last important event preserved in cores, occurred after 1822 A.D. (peak 7) but before 1954 A.D. and no other comparable event was verified later on. For these reasons an average recurrence time of $0.15 \mathrm{ky}$ seems more faithful to the reality and comparable with the return period of extreme events statistically computed.

\section{Methods and materials}

\subsection{Seismic and core stratigraphic data}

Some geological constrains to implement the model of coastal circulation were provided from the real stratigraphic and sedimentologic context of the last $1 \mathrm{ky}$ marine sequence of the Salerno Bay. In particular information is provided by four gravity cores (Fig. 2), collected between 1996-2002 and correlated through physical properties (magnetic susceptibility and chromaticity) to the paleomagnetically dated core C836 (Iorio et al., 2004; Sagnotti et al., 2005), in order to characterize and date event beds and tephra. These field data, gathered from previous studies (Budillon et al., 2005a, b) and here resumed, were integrated hereby with three more elements:

- Subbottom Chirp lines interpretation to gather information about extension, thickness and lateral continuity of sand layers. Their resolvable sections were traced throughout the northern Salerno Bay and crossed with eachother to reconstruct their spatial continuity in 3-D. The VHR Sub-bottom lines were acquired in 1998 by IAMC-CNR for marine geological mapping purposes. 
- AMS ${ }^{14} \mathrm{C}$ calibration on a Dentalium shell from C1064 core at $-80 \mathrm{~cm}$ to confirm the age model of event beds and in particular of $\mathrm{T} 1$ layer. The analysis was carried out with an AMS system based on the 9SDH-2 Pelletron accelerator, produced by National Electrostatics Corp., Middleton, WI (USA) and recently installed at CIRCE (Centre for Isotopic Research on Cultural and Environmental Heritage), "Seconda Università di Napoli", in Caserta (Italy);

- specific weight measurements of sand taken at IAMC/CNR sedimentological laboratory to implement sediment transport models; two grain size classes $(63 \mu \mathrm{m}<\phi<90 \mu \mathrm{m} ; 30 \mu \mathrm{m}<\phi<63 \mu \mathrm{m})$ were determined on sand and silt from T1 sand layer by using a common pychnometre.

\subsection{Circulation model}

For the numerical simulation the SHORECIRC program was used, since it is considered one of the most used models to compute the evolution of horizontal velocities of the nearshore circulation field in all three dimensions (and time). It was developed at the University of Delaware (Putrevu and Svendsen, 1999; Svendsen and Putrevu, 1994), and successfully compared to data from the DUCK94 and SandyDuck field experiments and with laboratory measurements (Haas and Svendsen, 2002).

The model is based on the computation of depthintegrated, time-averaged governing equations of motion, calculating nearshore current velocities in a two-step process. SHORECIRC first calculates horizontal gradients in hydrodynamic entities such as radiation stress and mass flux. These gradients drive currents and infragravity wave motions in the 2-D horizontal plane. This calculation gives $\mathrm{u}(\mathrm{x}, \mathrm{y})$ and $\mathrm{v}(\mathrm{x}, \mathrm{y})$, where $\mathrm{u}$ and $\mathrm{v}$ are the $\mathrm{x}$-directed and $\mathrm{y}$-directed velocity components respectively, and $\mathrm{x}$ and $\mathrm{y}$ denote location on a rectangular grid; then it calculates the 1-D vertical variation in velocity at each grid point to give $\mathrm{u}(\mathrm{x}, \mathrm{y}, \mathrm{z})$. A depth-integrated wave-averaged model is used to provide a full 3-D depiction of nearshore circulation that is needed to find out sediment transport patterns in the study area. Due to the limited time and space dimensions of the considered phenomena, the Ekman effects on coastal circulations were not taken into account (Shapiro et al., 2004).

A rectangular staggered grid to solve equations of motion for assigned time step $(\Delta t)$ was employed. To ensure the model stability the following inequality must be verified:

$\Delta t \leq 0.5 h / \sqrt{g \cdot a \cdot \Delta x}$

where $h$ is the maximum water depth, $a$ is the wave amplitude and $\Delta x$ is the grid step in $\mathrm{x}$ direction. For our purposes an equally spaced grid with $\Delta x=\Delta y=100 \mathrm{~m}$ with $\Delta \mathrm{t}=0.5 \mathrm{~s}$ to compute $\mathrm{u}(\mathrm{t})$ and $\mathrm{v}(\mathrm{t})$ was here adopted. The total runtime was fixed at $15 \mathrm{~h}$, consistently with duration of southern Tyrrhenian storm events. Generally sea storms reach a peak with maximum waves height after a phase of increment, which is highly variable depending on the atmospheric conditions; this factor has been neglected in the simulations. The same considerations can be maintained for the decreasing phase of the sea storms and thus only the peak phase of the sea storm was evaluated. This generalization does not affect the simulation since the aim is to verify the maximum depth at which sand resuspention and motion is possible under an extreme sea storm event.

\subsection{Sediment transport model}

For a cohesionless sediment the individual sediment grains rest and stay on the bottom due to their submerged weight and resist horizontal motion due to the presence of neighbouring grains. The ratio of mobilizing (drag) and stabilizing (submerged weight) forces is of fundamental physical significance in fluid-sediment interaction for cohesionless sediment. This ratio is known as the Shields parameter (Shields, 1936). When flow and sediment characteristics combine to produce a Shields parameter greater than the critical value, sediment is set in motion.

Several empirical bed load transport formulas have been proposed for turbulent boundary layer flows (Raudkivi, 1976). Among these, the Meyer-Peter and Müller formula (Meyer-Peter and Müller, 1948), enjoys particular popularity in the engineering literature. However, since it was originally developed from data obtained for steady flows in rivers and channels of negligible slope, its adoption for unsteady wave or combined wave-current turbulent boundary layer flows over an inclined bed is not straightforward. A conceptual model for bed-load transport of sediment grains (Madsen et al., 1993) rolling or sliding along an inclined bottom has been proposed by Madsen (1994) as a physical interpretation of the purely empirical Meyer-Peter and Müller formula.

The model is suited for the prediction of offshore sediment transport rate under sea storm events thus it serves the purpose of this study. The governing equation inserted in the model are presented below.

The net transport $q_{\text {net }}$ at the sea bottom in the presence of waves is computed as the averaged instantaneous transport $\mathrm{q}_{s}(\mathrm{t})$ over the cycle of a wave period $\mathrm{T}$ :

$q_{\mathrm{net}}=\frac{1}{T} \int_{0}^{T} q_{s} \cdot(t) \cdot d t$

The instantaneous value of sediment transport is computed using a formula which is based on an earlier empirical relationship known as the Einstein-Brown formula (Brown, 1950) for bottom sediment transport.

During portions of the wave period the flow can be considered unidirectional and steady. The instantaneous 
dimensional sediment transport rate, is expressed in the following equation:

$q(t)=w \cdot d \cdot\left\{\frac{0.5 \cdot \rho \cdot f_{c w} \cdot\left[u^{2}(t)+v^{2}(t)\right]}{\left(\rho_{s}-\rho\right) \cdot g \cdot d}\right\}^{3}$

where $\rho$ is the fluid density, $\rho_{s}$ is the bulk density of sediment, $d$ is the mean sediment grain size, $w$ is the fall velocity of sediment, $f_{w c}$ is the combined wave-current friction factor, and $u$ and $v$ are the velocity components that result from the combination of high frequency (wave driven) and lowfrequency (atmospheric and tide driven) currents. A method for computing $f_{w c}$ is given by Madsen (1994), which is essentially an iterative method that modifies the bottom boundary layer based on interaction with waves. Initially, the wave friction factor for waves in the presence of currents is determined by using the equation:

$\frac{1}{4 \cdot \sqrt{f_{w c} / C_{\mu}}}+\log \cdot \frac{1}{4 \cdot \sqrt{f_{w c} / C_{\mu}}}=\log \frac{C_{\mu} \cdot u_{b}}{k_{s} \cdot \omega}-0.17$

where $k_{s}$ is the characteristic bottom roughness, $\omega$ is the wave radian frequency $(2 \pi / \mathrm{T}), u_{b}$ is the magnitude of the velocity under the wave (in linear wave theory), and the coefficient $C_{\mu}$ is described as:

$C_{\mu}=\left(1+2 \cdot \mu \cdot \cos \theta_{c}+\mu^{2}\right)^{1 / 2}$

where

$\mu=\left(\frac{u_{* c}}{u_{* w m}}\right)^{2}$

and $\theta_{c}$ is the angle between the wave approach and the current direction, $u_{* c}$ is the current shear velocity, and $u_{* w m}$ is the magnitude of the maximum wave shear velocity in the presence of currents. In this procedure, an initial guess for the value of $\mu$ must be attempted, using a verisimilar value (e.g. based on specific literature), because $u_{* w m}$ is initially unknown. The final value of $f_{c w}$ is computed using the equation:

$f_{c w}=2 \cdot\left(\frac{u_{* c}}{u_{r}}\right)^{2}$

where $u_{r}$ is the magnitude of the measured current at a particular height above bottom, $z_{r}$. The current shear velocity is determined by the equation:

$u_{r}=\frac{u_{* c}}{\kappa} \cdot\left(\ln \frac{z_{r}}{\delta_{w c}}+\frac{u_{* c}}{u_{* m}} \cdot \ln \frac{\delta_{w c}}{z_{0}}\right) ;$ for $z_{r}>\delta_{c w}$

$u_{* w m}^{2}=\frac{1}{2} \cdot f_{w c} \cdot u_{b}^{2}, \quad u_{* m}^{2}=C_{\mu} \cdot u_{* w m}^{2}, \quad \delta_{c w}=\frac{\kappa \cdot u_{* m}}{\omega}(11)$

where $u_{* m}$ is the combined wave current shear velocity, $\delta_{w c}$ is the bbl thickness and $\kappa$ is the von Karman's constant $(=0.4)$.

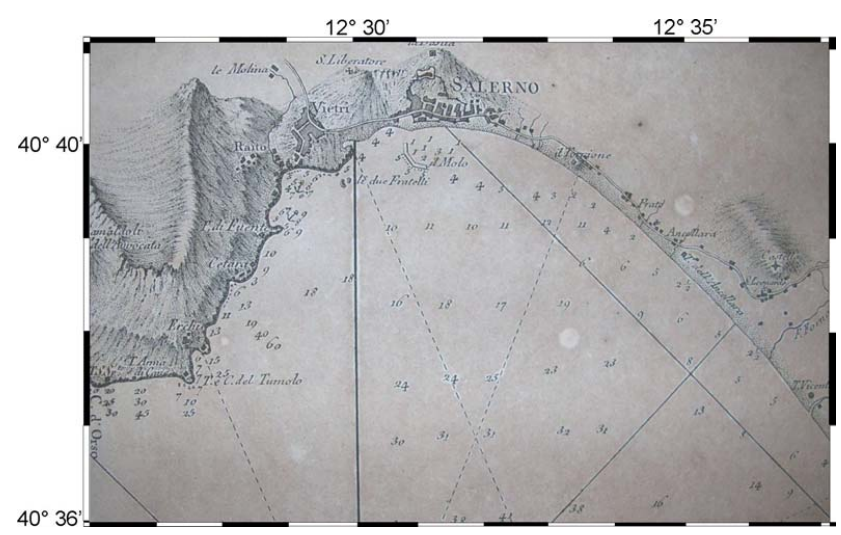

Fig. 4. Detail of the Salerno Bay nautical by Rizzi Zannoni (1792). Water soundings are in fathoms (about $1.62 \mathrm{~m}$ ); longitudes are referred to the meridian of the Paris Astronomic Observatory.

\subsection{Cartographic references}

In order to correctly simulate the coastal circulation that most likely led to the deposition of the sand layers under sea storm conditions, the bathymetry and the coastline relative to the time of considered events were computed. In the 16th century however no quantitative mapping had been developed and the construction of maps was mainly an artistic representation of qualitative geographical observations. Only at the end of the 18th century the development of triangulation methods led to the creation of reliable maps.

The royal topographic office of the "Regno delle due Sicilie", directed by the geographer Rizzi Zannoni started the mapping of coastal areas of Southern Italy in 1782 and took accurate soundings of water depths for nautical purposes (Fig. 4). Depth reported onto the 1792 A.D. map are consistent with the depth calculated by removing the interval deposited during the 19th-20th centuries at the core sites C1064, C6 and C839. The map was then digitalized and georeferenced using tie points along the unchanged rocky coast; it constitutes the topographic base to model the coastal circulation under the exceptional storm conditions that most likely occurred in the 19th century, to tentatively simulate the deposition of $\mathrm{T} 1$ event bed.

\section{Results}

\subsection{Stratigraphic data}

By means of seismic stratigraphic interpretation matched with cores, it has been possible to follow the reflections bouncing back from sand layers T1, T2 and T3 (Fig. 2) and define the area where they settled with a thickness higher than the instrument resolution $(30 / 40 \mathrm{~cm})$. Below this thickness no clear reflection comes out from the sub-bottom and reflectors interrupt. Reflections are also masked due to the 


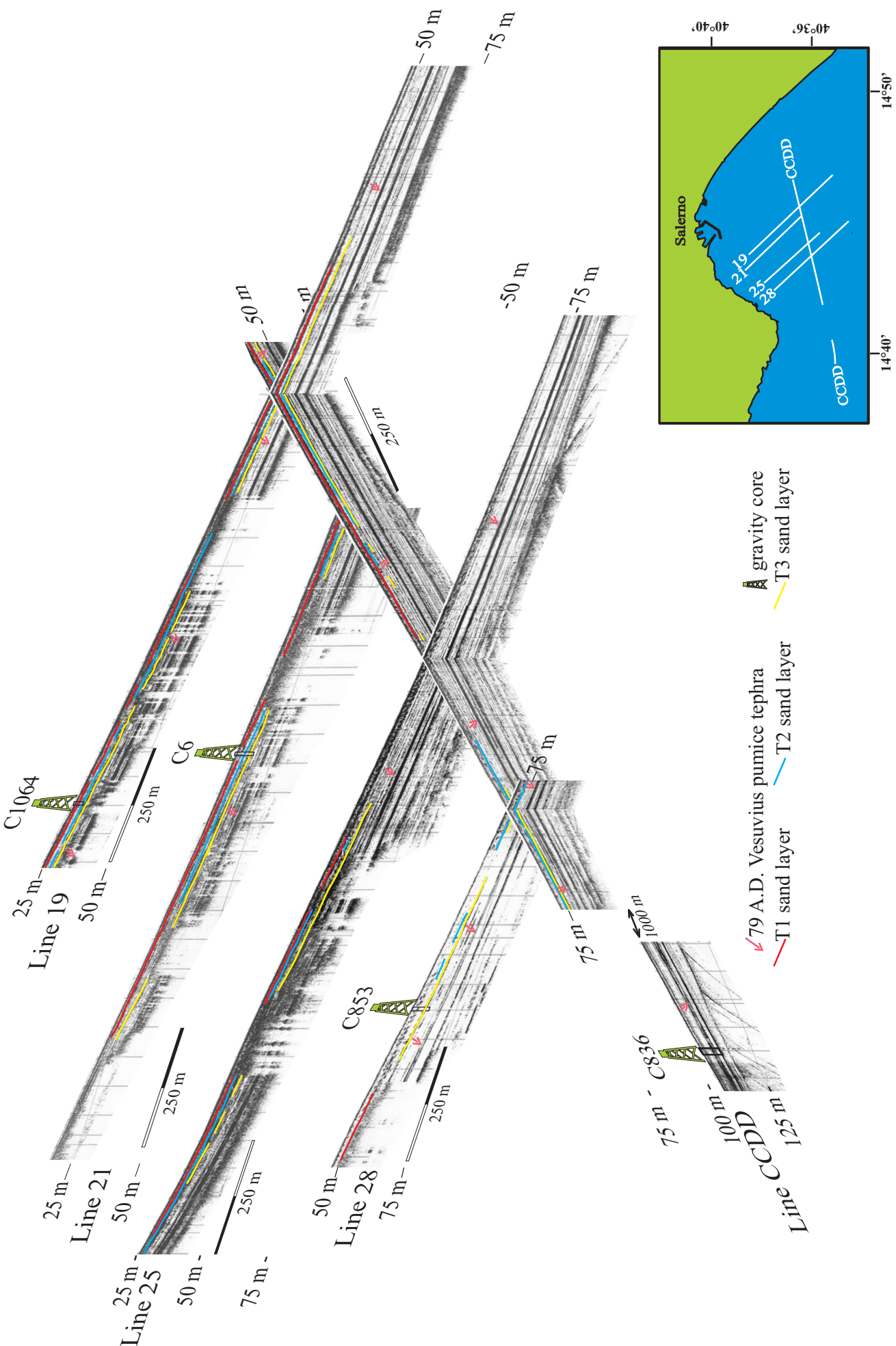

Fig. 5. High resolution Subbottom Chirp lines show the Holocene stratigraphic frame of the Salerno Bay northern sector. Three reflectors bouncing back from T1, T2 and T3 sand layers are outlined with red, light blue and yellow lines; the one from the pumice deposit of the 79 A.D. Vesuvius plinian eruption is pointed out with red arrows. 
Table 2. Resume of main characteristics of T1, T2, T3 tempestite deposits coming from sedimentologic, lithostratigraphic and seismicstratigraphic observations.

\begin{tabular}{|c|c|c|c|c|c|c|}
\hline & $\begin{array}{l}\text { C1064 }(-29 \mathrm{~m}) \\
\text { Lat. } 40^{\circ} 38.55^{\prime} \\
\text { Long. } 14^{\circ} 43.99^{\prime}\end{array}$ & $\begin{array}{l}\text { C6 }(-37 \mathrm{~m}) \\
\text { Lat. } 40^{\circ} 38.15^{\prime} \\
\text { Long. } 14^{\circ} 44.10^{\prime}\end{array}$ & $\begin{array}{l}\mathrm{C} 839(-38 \mathrm{~m}) \\
\text { Lat. } 40^{\circ} 38.03^{\prime} \\
\text { Long. } 14^{\circ} 44.04^{\prime}\end{array}$ & $\begin{array}{l}\mathrm{C} 853(-62 \mathrm{~m}) \\
\text { Lat. } 40^{\circ} 37.29^{\prime} \\
\text { Long. } 14^{\circ} 43.38^{\prime}\end{array}$ & $\begin{array}{l}\text { Approx. } \\
\text { age }\end{array}$ & $\begin{array}{l}\text { Seismic features of } \\
\mathrm{T} \text { reflectors }\end{array}$ \\
\hline $\mathrm{T} 1$ & $\begin{array}{l}\text { tckn. } 25 \mathrm{~cm} \\
\text { max g.s. } 250 \div 125 \phi \\
g . f . \text { norm. graded } \\
\text { tx. well sorted } \\
\text { base sharp erosive } \\
\text { top gradual to silt }\end{array}$ & $\begin{array}{l}\text { tckn. } 3 \mathrm{~cm} \\
\text { max g.s. } 63 \phi \\
\text { tx. moder. sorted } \\
\text { base sharp } \\
\text { top gradual to mud }\end{array}$ & $\begin{array}{l}\text { tckn. } 4 \mathrm{~cm} \\
\text { max g.s. } 63 \div 30 \phi \\
\text { tx. moder. sorted } \\
\text { base sharp } \\
\text { top gradual to mud }\end{array}$ & $\begin{array}{l}\text { tckn. } 4 \mathrm{~cm} \\
\text { max g.s. } 63 \div 30 \phi \\
\text { tx. moder. sorted } \\
\text { base gradual } \\
\text { top gradual to mud }\end{array}$ & $\begin{array}{l}\text { 19th cen- } \\
\text { tury }\end{array}$ & $\begin{array}{l}15-60 \mathrm{~m} \\
\text { laterally continuous, } \\
\text { variable amplitude, } \\
\text { ring shaped in plan } \\
\text { view, lower limit ir- } \\
\text { regular. }\end{array}$ \\
\hline $\mathrm{T} 2$ & $\begin{array}{l}\text { tckn. }>17 \mathrm{~cm} \\
\text { max g.s. } 250 \div 125 \phi \\
\text { tx. well sorted } \\
g . f . \text { norm. graded } \\
\text { base not depicted } \\
\text { top gradual to mud }\end{array}$ & $\begin{array}{l}\text { tckn. } 80 \mathrm{~cm} \\
\text { max g.s. } 125 \div 63 \phi \\
g . f .- \text { norm. graded, } \\
\text { parallel laminated, } \\
\text { low angle laminated } \\
\text { tx. well sorted } \\
\text { base sharp erosive } \\
\text { top gradual to mud }\end{array}$ & $\begin{array}{l}\text { tckn. } 40 \mathrm{~cm} \\
\text { max g.s. } 125 \div 63 \phi \\
g . f .- \text { norm. graded } \\
\text { tx. well sorted } \\
\text { base not depicted } \\
\text { top gradual to mud }\end{array}$ & absent & $\begin{array}{l}16 \text { th cen- } \\
\text { tury }\end{array}$ & $\begin{array}{l}20-45 / 65 \mathrm{~m} \text {, } \\
\text { variable amplitude, } \\
\text { crenulated and dis- } \\
\text { rupted in depth, ori- } \\
\text { ented southward }\end{array}$ \\
\hline T3 & not sampled & $\begin{array}{l}\text { tckn. } 22 \mathrm{~cm} \\
\text { max g.s. } 125 \div 63 \phi \\
g . f .- \text { massive, } \\
\text { parallel laminated } \\
\text { tx. well sorted } \\
\text { base sharp erosive } \\
\text { top gradual to mud }\end{array}$ & not sampled & $\begin{array}{l}\text { tckn. } 35 \mathrm{~cm} \\
\text { max g.s. } 125 \div 63 \phi \\
g . f .- \text { norm. graded } \\
\text { tx. well sorted } \\
\text { base sharp erosive } \\
\text { top gradual to mud }\end{array}$ & $\begin{array}{l}\text { 11th cen- } \\
\text { tury }\end{array}$ & $\begin{array}{l}18-75 \mathrm{~m} \\
\text { high amplitude, } \\
\text { lateral discontinu- } \\
\text { ous } \\
\text { lobe shaped in plan } \\
\text { view }\end{array}$ \\
\hline
\end{tabular}

local presence of shallow gas, likely biogenic, that impregnates porous sand and is sealed by overlying mud. Thus seismic reflectors corresponding to sand layers are laterally discontinuous and often occur as lens parallel to the coast and locally appear with changing amplitudes due to the varying thickness of the deposits; nevertheless they are traceable over a wide area up to a distance of $5 \mathrm{~km}$ from the Salerno coast and close landwards against an erosive surface that develops at about $18 \mathrm{~m}$ of depth (21 Chirp line, Fig. 5):

- the T1 reflector extends more or less continuously around the site C1064 and C6 core and closes southwards, thus not reaching the C853 core; it shows a curved shape in plan view following the natural trace of the coast;

- the T2 reflector seems less widespread and continuous than $\mathrm{T} 1$, but being locally very thick, it appears at places as two closely spaced reflections, probably due to the variation of acoustic impedance at its top and bottom; it is triangle shaped in a plan view with a vertex pointing southwards;

- the T3 reflector extends down to about $75 \mathrm{~m}$ of depth at the most and occurs as two elongated lobes apparently oriented south-eastwards; being the inmost one it is frequently interrupted by the gas pockets and thus it is less traceable than $\mathrm{T} 1$ and $\mathrm{T} 2$.
Main characteristics of the sand layers and relative reflectors are summarized in Table 2.

The ${ }^{14} \mathrm{C}$ age calibration made on a Dentalium shell at $-75 \mathrm{~cm}$ in $\mathrm{C} 1064$ core (immediately above the T1 sand layer) resulted in a $\mathrm{RC}$ age of $467(\Delta \mathrm{r} \pm 33)$, thus outside the marine samples calibration curve (Stuiver and Reimer, 1993) because modern (1850-1950 A.D.). This value, even though vague, is in agreement with the age model attempted in Budillon et al. (2005a, b), that attributed T1 to the middle part of the 19th century. This age confirms that at least one extreme event occurred in the last $0.15 \mathrm{kyr}$ and corroborates the choice of a $100 \mathrm{y}$ return period of extreme sea storms.

Laboratory determination of specific weight of fine sand and silt sampled at $\mathrm{T} 1$ sand layer, gave reliable values in agreement with standard ones $(63 \leq x \leq 90$ micron: $2.683 \mathrm{~g} / \mathrm{cm}^{3} ; 30 \leq x \leq 63$ micron: $2.714 \mathrm{~g} / \mathrm{cm}^{3}$ ) and were then used to implement the sediment transport numerical models.

\subsection{Numerical simulation}

The simulation was run moving from deep water conditions located at $115.0 \mathrm{~m}$ of depth and taking into account refraction-diffraction effects. The wave height used for the simulation was chosen at return period $\mathrm{T}_{r}=0.1 \mathrm{ky}$ $\left(\mathrm{H}_{s, T r}=8.00 \mathrm{~m}, \mathrm{~T}_{s, T r}=13 \mathrm{~s}\right)$ which assumes the value of $\mathrm{H}=7.15 \mathrm{~m}$ at the location of C1064 (29 $\mathrm{m}$ of depth) and $\mathrm{H}=7.27 \mathrm{~m}$ at the location of C6 (38 $\mathrm{m}$ of depth). These values 

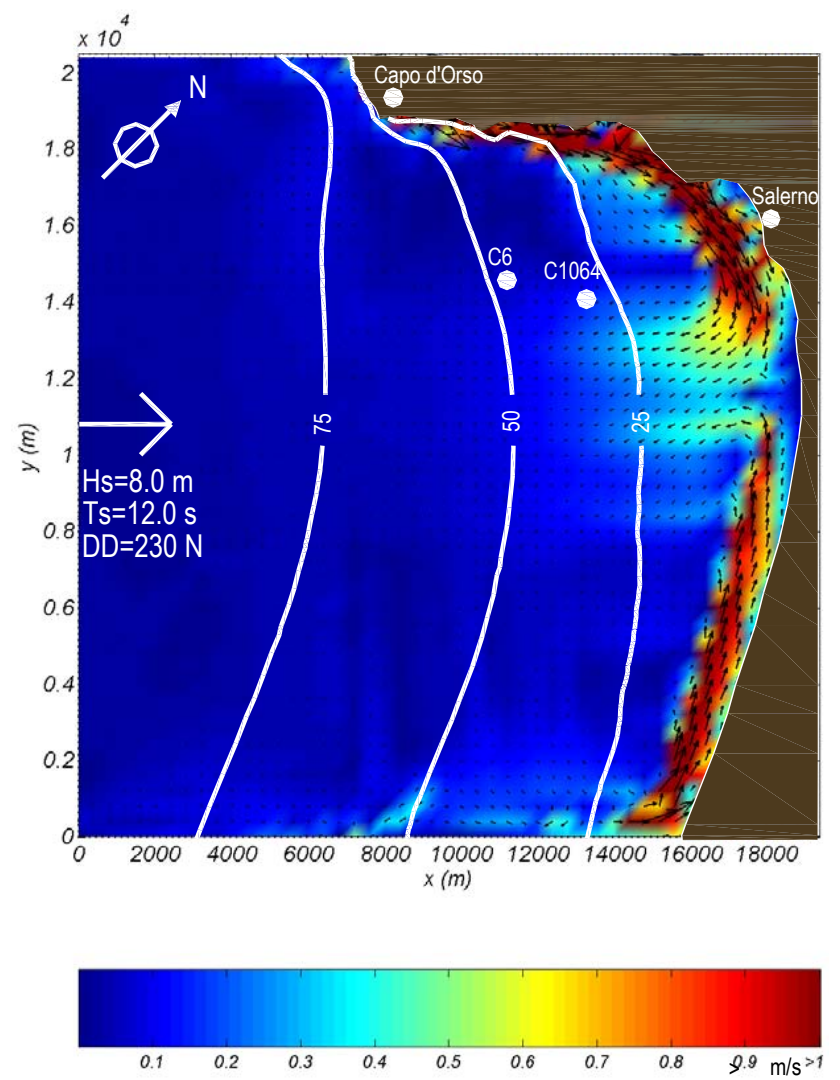

Fig. 6. Predicted 2DH current vector map.

are used as reference in the calculation of near bed wave orbital velocity at the same sites.

The circulation model simulation shows the formation of a crosshore current directed seawards with a direction $215^{\circ} \mathrm{N}$ (Fig. 6). This current is generated from the interaction between two longshore currents having opposite directions, one clockwise from Capo d'Orso to the south and the other anticlockwise, from the southeast toward Capo d'Orso. This crosshore current reaches the maximum velocity in proximity of the surf zone $(\mathrm{h}=10 \mathrm{~m})$ and decreases offshore down to the depth of about $60 \mathrm{~m}$. The $2 \mathrm{DH}$ mean value of current velocities near $\mathrm{C} 1064$ and $\mathrm{C} 6$ sites are, respectively, $\mathrm{u}_{r}=1.45 \mathrm{~m} / \mathrm{s}$ and $\mathrm{u}_{r}=0.96 \mathrm{~m} / \mathrm{s}$ after $3 \mathrm{~h}$. The mentioned values remain constant for the rest of the simulation. This current coupled with oscillatory motion controlled wave and directed $230^{\circ} \mathrm{N}$ generates a nested current in the bbl that accounts for fine sand net transport down slope. It is worth noting that the direction of the net sediment transport is not the direction of the crosshore current but is obtained by:

$$
\tan \theta_{t}=\frac{2}{3} \cdot \tan \theta_{c}
$$

where $\theta_{t}$ is the direction of the net bed-load transport measured counter clockwise from the $\mathrm{x}$ axis, that in this case is $220^{\circ} \mathrm{N}$ (Madsen, 1994).
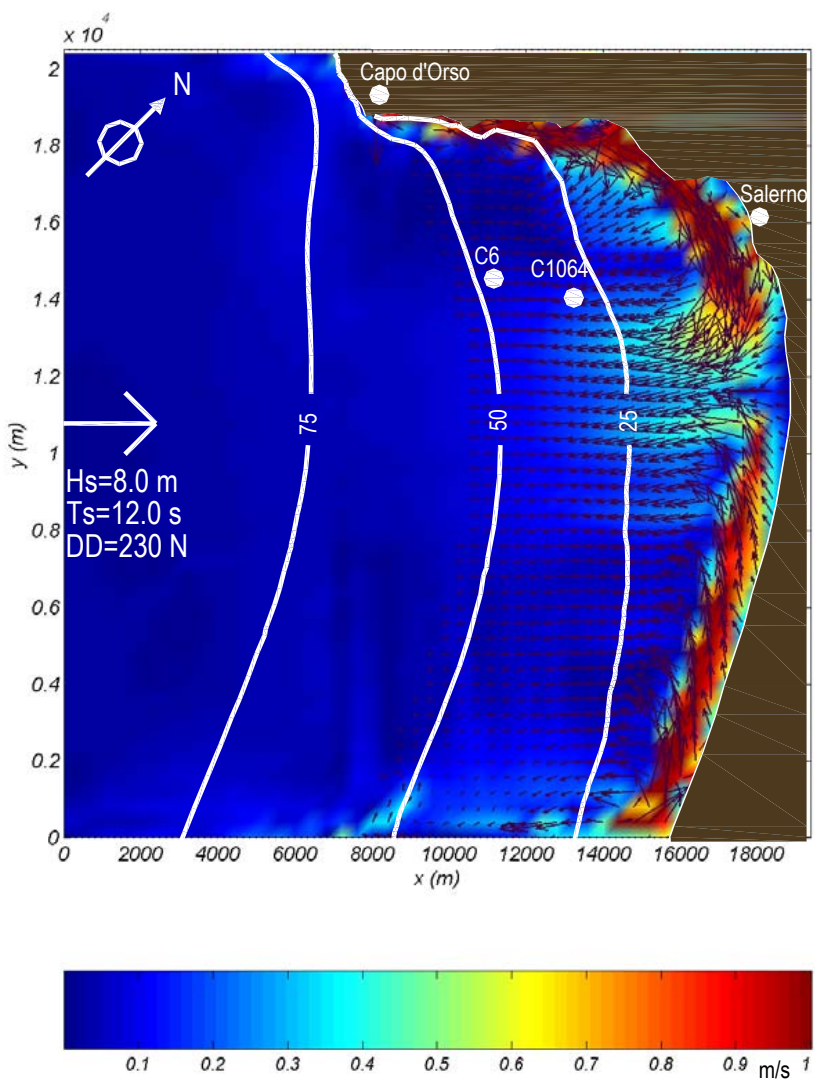

Fig. 7. Predicted near bed velocity vector map.

The near bed current velocity in the surf zone is mainly directed longshore, as expected; immediately outside the breaking zone the near bed current turns crosshore, since the oscillatory motion becomes predominant with respect to the currents driven by radiation stresses (Fig. 7).

In Fig. 8 the potential sediment transport rate for the investigated area is represented. The color map provides a visual scale to determine the rate of transport per cell width (cell width $=100 \mathrm{~m}$ ). The combined wave current velocity is high enough to move sediment at the C1064 and C6 sites, and the resulting sediment transport rate is towards the southwest, according to maximum wave induced orbital velocities and bottom currents.

As shown in Fig. 8 the potential net transport concentrates forming fan shaped lobes enlarging seawards. Three main macrocells with maximum lateral variability are recognizable to the right side of the picture from the bathymetric of about $7 \mathrm{~m}$ down to about $25 \mathrm{~m}$ of depth and correspond to the source area of littoral sand transported down slope. The almost continuous $7 \mathrm{~m}$ deep alignment corresponds to the breaking line for the extreme sea storm wave high, above which sediment transport is directed longshore as expected, according to surf zone dynamics (Fig. 6). It is worth noting that only offshore directed sediment transport has been plotted in Fig. 8, while surf zone dynamic has been neglected. At 
Table 3. Predicted circulation and sediment transport values.

\begin{tabular}{lllllll}
\hline & $\mathrm{u}_{r}(\mathrm{~m} / \mathrm{s})$ & $\mathrm{u}_{b}(\mathrm{~m} / \mathrm{s})$ & $\mathrm{u}_{* w m}(\mathrm{~m} / \mathrm{s})$ & $\mathrm{u}_{* m}(\mathrm{~m} / \mathrm{s})$ & $\delta_{c w}(\mathrm{~m})$ & $\mathrm{q}(\mathrm{m} 3 / \mathrm{m} \mathrm{s})$ \\
\hline C1064 & 1.45 & 0.31 & 0.63 & 0.39 & 0.04 & 0.62 E04 \\
C6 & 0.96 & 0.24 & 0.45 & 0.17 & 0.03 & 0.25 E04 \\
\hline
\end{tabular}

a depth of $50 \mathrm{~m}$ an homogeneity can be observed in regard to net transport, while more in depth lateral variation of net transport comes into sight and appears as lobe shaped cells down to the depth of $80 \mathrm{~m}$, where a residual net transport of the finest particles is still possible.

The magnitude of sediment transport rate (q) at sites are reported in Table 3. Moreover, the values of $\mathbf{u}_{r}$ (computed current velocity), $\mathrm{u}_{b}$ wave orbital velocity at the bottom (linear theory), $\mathrm{u}_{* w m}$ the maximum wave shear velocity in presence of current, $\mathrm{u}_{* m}$ combined wave current shear velocity, $\delta_{c w}$ the thickness of the bottom boundary layer are also reported.

\section{Discussion}

Sand seems to contribute consistently to the aggradation of the inner shelf since the $18 \%$ of the total thickness of the C1064 core, the $22 \%$ of the C6 core and the $10 \%$ of the C853 core is made up with particles coarser than silt. This observation is confirmed even by seismic lines where the maximum sediment thickness is measured between $30-60 \mathrm{~m}$ of depth, if the beach wedge is neglected, and laterally continuous high amplitude reflections are evident (Fig. 5).

The numerical simulations highlight that at sites where cores disclose sand layers, the kinematic condition at the sea bottom is intense enough, after three hours, to start up and keep on a net solid transport relatively to fine and very fine sand particles. It is assumed that as the sea storm begins to wane, the kinematic conditions decrease, $\mathrm{u}_{* m}$ slows down, and the net solid transport goes on only for finest particles that are excluded from the considered core sites. Thus, a vertical and an horizontal sorting of grains could take place at the end of the process as verified in cores and in seismic lines.

The most impacted area, as resulted from the numerical model, is located between $10 \mathrm{~m}$ and $20 \mathrm{~m}$ of depth between Salerno and Capo d'Orso. Seismic lines evidence an extensive coarse grained erosive surface at the sea bottom down to about $18 \mathrm{~m}$, that interrupts sub-bottom reflections with toplap or truncated lateral terminations. This area corresponds to a bypass sector with respect to the extreme storm conditions and is made up of the remaining coarser sediment fractions, with prograding, wedge shaped stacking pattern. Proceeding seaward the $\mathrm{T}$ reflectors are laterally discontinuous and show variable amplitudes; these features might be accounted for by the shape of net transport cells as evidenced by the transport numerical model (Fig. 7), that seems to concentrate in lobes obliquely to the coast. $\mathrm{T}$ reflectors are widespread and laterally continuous in the bathymetric range of about $40 \mathrm{~m}$ of depth where the numerical simulation evidences a more homogeneous net transport; in this area it is more likely that uninterrupted sand sheets deposited when shear velocities decrease.

The numerical simulation shows that $\mathrm{u}_{* m}$ velocity at sites C1064 and C6, where T1 sand layer occurs, is intense enough to transport sand over about $0.5 \mathrm{~km}$ during a $3 \mathrm{~h}$ time span (typical duration of a sea storm peak in the Southern Tyrrhenian Sea), before settling down. This result is only indicative since $\mathrm{u}_{* m}$ values change with depth and time following the typology of the storm. Since extreme events are generally accompanied by increasing and decreasing phases with significant wave heights that might uphold combined flows in the bbl, it is likely that much longer distances could be covered by sand particles during the whole storm event.

However the T2 sand layer is thicker than $\mathrm{T} 1(80 \mathrm{~cm}$ at C6 core site) and theT3 seismic reflector reaches $70 \mathrm{~m}$ of depth and shows high amplitude that lead to suppose a consistent thickness of sand. Although the maximum depth for fine sand resuspension corresponds to $75 \mathrm{~m}$ during the extreme sea storm possible, it is difficult to explain such thickness of single layers as being the result of a single storm event. Being the possibility of more intense sea storms (waves trend higher than $8 \mathrm{~m}$ are not compatible with the fetch length) ruled out, two hypothesis should be considered:

- the duration of the sea storm events that generated the $\mathrm{T} 2$ and the T3 layers were consistently longer than $15 \mathrm{~h}$;

- sand particles forming the T2 and T3 layers were winnowed from the offshore and thus had to cover shorter distance to reach respectively $40 \mathrm{~m}$ and $75 \mathrm{~m}$.

Concerning the first hypothesis, it is unlikely that any sea storm had lasted longer than $15 \mathrm{~h}$, in the assumption that the wind wave climate was similar to present, but is less unlikely if a different wind wave climate over the L.I.A. is supposed.

In regards to the second hypothesis, it should be considered that a previous less intense sea storm with a return period shorter than $0.1 \mathrm{ky}$ possibly occurred shortly before the 16 th and 11th century driving sand offshore.

However, the contribution from riverine discharge under extreme rainfall condition, such as hyperpycnal flows, 

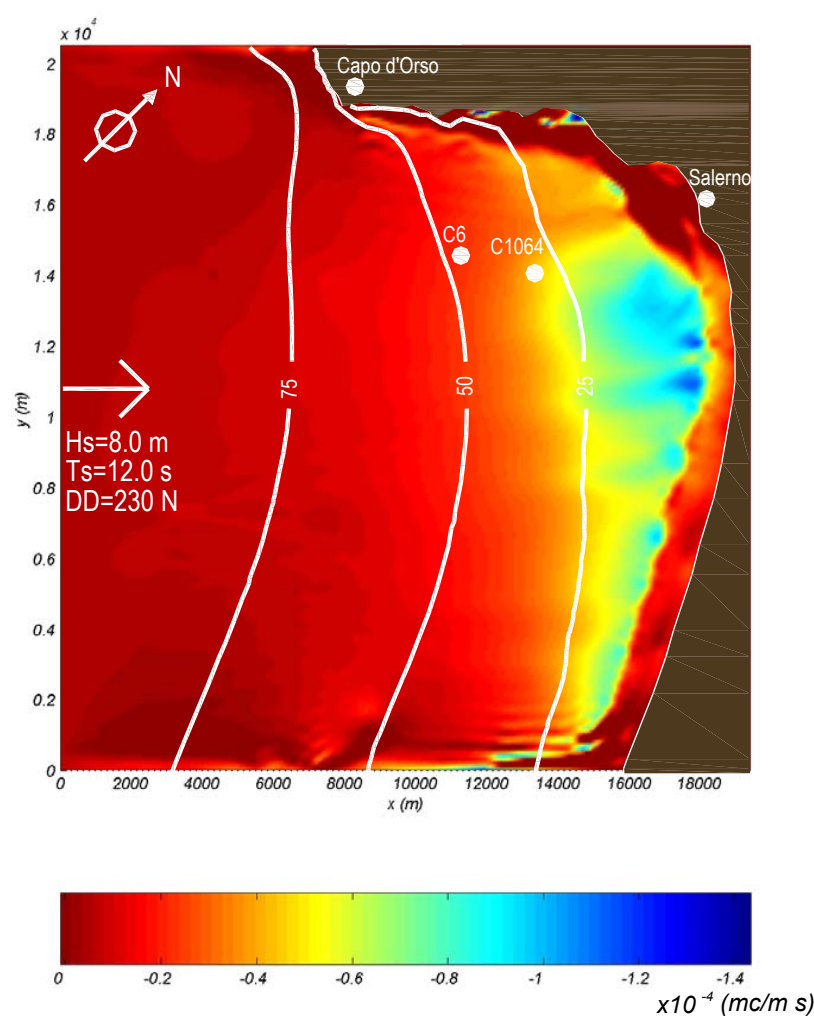

Fig. 8. Predicted potential sediment transport rate.

cannot be ruled out since it has been verified that mountainous streams along the Salerno coast recurrently underwent floods. Coarse grained deposits derived from flash floods occur down to $30 \mathrm{~m}$ of depth as testified by $\mathrm{C} 1064$ core and geophysics surveys (Esposito et al., 2004; Violante and Budillon, 2004). Finally we do not exclude the possibility that gravity driven displacement from nearshore sand bars may have occurred in extreme wave conditions where the seabed deepens enough to uphold the motion. However this hypothesis needs further investigation to be confirmed.

\section{Conclusions}

In order to confirm the origin inferred to the $\mathrm{T}$ layers (seastorm deposition) occurring in the stratigraphic record of the Salerno Bay shelf, a modelling of coastal circulation and sediment transport under sea-storm condition was performed. An hypothetical extreme sea storm was considered with a return period of $0.1 \mathrm{ky}$, a direction from $230^{\circ} \mathrm{N}$ and significant wave heights of about $8 \mathrm{~m}$ and a period $\mathrm{T}_{s}$ of about $13 \mathrm{~s}$ have been used to implement the numerical simulations.

Results highlight that at $\mathrm{C} 1064$ and $\mathrm{C} 6$ sites (correspondingly $29 \mathrm{~m}$ and $37 \mathrm{~m}$ of depth) $2 \mathrm{DH}$ current velocities are respectively $1.45 \mathrm{~m} / \mathrm{s}$ and $0.96 \mathrm{~m} / \mathrm{s}$. The magnitude of the combined wave-current shear velocity at sites reaches $0.39 \mathrm{~m} / \mathrm{s}$ and $0.17 \mathrm{~m} / \mathrm{s}$ and accounts for a sediment transport rate of
$0.62 \cdot 10^{-4} \mathrm{~m}^{3} / \mathrm{ms}$ and $0.25 \cdot 10^{-4} \mathrm{~m}^{3} / \mathrm{ms}$. These value are compatible to justify the formation of the T1 layer during an extreme sea storm, nevertheless more variables (storm duration, time distribution of wave heights and different sediment grain size) are necessary to implement the numerical simulations in order to corroborate the formation of the $\mathrm{T} 2$ and the T3 layers which are much thicker and deep than the T1 tempestite.

Acknowledgements. We are grateful to C. Lubritto of Second University of Naples, for ${ }^{14} \mathrm{C}$ calibrations at Circe Laboratory, B. D'Argenio and E. Marsella of IAMC-CNR for encouraging this research. T. S. Hopkins, P. Ciavola, and an anonymous referee are sincerely acknowledged for their helpful suggestions to the improvement of the manuscript. Finally we are grateful to the Engineering and Marine Sciences $\mathrm{PhD}$ program of Federico II University. We also thank P. Sclafani for correcting the English.

Edited by: A. Mugnai

Reviewed by: P. Ciavola and another referee

\section{References}

Andrade, C., Freitas, M. C., Moreno, J., and Craveiro, S. C.: Stratigraphical evidence of Late Holocene barrier breaching and estreme storms in lagoonal sediments of Ria Formosa, Algarve, Portugal, Mar. Geol., 210, 339-362, 2004.

Antonioli, F., Cremona, G., Immordino, F., Puglisi, C., Romagnoli, C., Silenzi, S., Valpreda, E., and Verrubbi, V.: New data on the Holocenic sea level rise in NW Sicily (Central Mediterranean Sea), Global and Planetary Change, 716, 121-140, 2002.

Bradley, R. S. and Jones, P. D.: "Little Ice Age" summer temperature variations: their nature and relevance to recent global warming trends, The Holocene, 3, 367-376, 1993.

Budillon, F., Esposito, E., Iorio, M., Pelosi, N., Porfido, S., and Violante, C.: The geological record of storm events over the last 1000 years in the Salerno Bay (Southern Tyrrhenian Sea): new proxy evidences, European Geoscience Union, Adv. Geosci., 2, 1-8, 2005a.

Budillon, F., Violante, C., Conforti, A., Esposito, E., Insinga, D., Iorio, M., and Porfido, S.: Event beds in the recent prodelta stratigraphic record of the small flood-prone Bonea stream (Amalfi Coast, Southern Italy), Mar. Geol., 222-223, 419-441, 2005 b.

Cacchione, D. A., Wiberg, P. L., Lynch, J. F., Irish, J. D., and Traykovski, P. A.: Estimates of suspended - sediment flux and bedform activity on the inner portion of Eel River continental shelf, Mar. Geology, 154(1-4), 83-97, 1999.

Cocco, E., de Magistris, M. A., Efaicchio, M. T., and Boscaino, F.: Geo-environmental features of the Sele river littoral plain (Gulf of Salerno, Southern Italy), Boll. Ocean. Teor. Appl., 10, 235246, 1992.

Conforti, A.: Stratigrafia integrata della sequenza TardoQuaternaria del settore settentrionale del Golfo di Salerno e di quello meridionale del Golfo di Napoli, Unpublished PHD thesis, Università Federico II di Napoli, pp. 144, 2003.

Dawson, S., Smith, D. E., Jordan, J., and Dawson, A. G.: Late Holocene coastal sand movements in the Outer Hebrides, N.W. Scotland, Mar. Geol., 210, 281-306, 2004. 
Dott, R. H. and Bourgeois, J.: Hummocky stratification: significance of its variable bedding sequence, Geological Soc. Amer. Bull., 93, 663-680, 1982.

Duke, W.: Hummocky cross-stratification, tropical hurricanes, and intense winter storms, Sedimentology, 32, 167-194, 1985.

Duke, W. L., Arnott, R. W. C., and Cheel, R. J.: Shelf sandstones and hummocky cross-stratification: new insights on a stormy debate, Geology, 19, 625-628, 1991.

Ellis, M. Y.: Coastal Mapping Handbook, Department of the Interior, U.S. Geological Survey and U.S. Department of Commerce, National Ocean Service and Office of Coastal Zone Management, U.S. Government Printing Office, Washington, D.C., 1978.

Esposito, E., Porfido, S., Violante, C., Biscarini, C., Alaia, F., and Esposito, G.: Water events and historical flood recurrences in the Vietri sul Mare coastal area (Costiera Amalfitana, southern Italy), Proceedings of the UNESCO/IAHS/IWHA symposium on The Basis of Civilization - Water Science?, Rome, IAHS Publ, 286, 2004.

Goda, Y.: On the methodology of selecting design wave height, 21st International Coastal Engineering Conference, Amer. Soc. Civil Eng., 899-913, 1988.

Grancini, G., Cavalieri, L., and Tosi, R.: Hindcast estimate of design wave conditions in the Tyrrhenian sea, Congresso AIOL, pp. 167-178, 1980.

Grant, W. D. and Madsen, O. S.: The Continental Shelf Bottom Boundary Layer, Ann. Rev. Fluid Mech., 18, 265-305, 1986.

Greenwood, B. and Sherman, D. J.: Hummocky cross-stratification in the surf zone: flow parameters and bedding genesis, Sedimentology, 33, 33-45, 1986.

Haas, K. A. and Svendsen, I. A.: Laboratory measurements of the vertical structure of rip currents, J. Geophys. Res., 107(C5), 3047, 2002.

Ingram, M. J., Underhill, D. J., and Wigley, T. M. L.: Historical climatology, Nature, 276, 329-334, Climatology Supplement, 1978.

Iorio, M., Sagnotti, L., Angelino, A., Budillon, F., D’Argenio, B., Dinares Turell, J., Macrì, P., and Marsella, E.: High-resolution petrophysical and paleomagnetic study of late-Holocene shelf sediments, Salerno Gulf, Tyrrhenian Sea, Holocene, 14(3), 433442, 2004.

Keen, T. R., Bentley, S. J., Chad Vaughan, W., and Blain, C. A.: The generation and preservation of multiple hurricane beds in the northern Gulf of Mexico, Mar. Geol., 210, 79-105, 2004.

Lamb, H. H.: Climatic variations and changes in the wind and ocean circulation: the Little Ice Age in the Northeast Atlantic, Quat. Res., 11, 1-20, 1979.

Madsen, O. S. and Wikramanayake, P. N.: Simple Models for Turbulent Wave-Current Bottom Boundary Layer Flow, Contract Report DRP-91-1, U.S. Army Engineer Waterways Experiment Station, Vicksburg, MS., 1991.

Madsen, O. S.: Spectral wave-current bottom boundary layer flows, Coastal Engineering, Proceedings, 24th International Conference, Coastal Engineering Research Council/ASCE, 384-398, 1994.

Madsen, O. S., Wright, L. D., Boon, J. D., and Chisholm, T. A.: Wind stress, bed roughness, and sediment suspension on the inner shelf during an extreme storm event, Cont. Shelf Res., 13(11), 1303-1324, 1993.
Meyer-Peter, E. and Müller, R.: Formulas for Bed-Load Transport, Report on Second Meeting of International Association for Hydraulic Research, 39-64, 1948.

Morton, R. A.: Formation of storm deposit by wind-forced currents in the Gulf of Mexico and the North Sea, in: Holocene Marine Sedimentation in the North Sea Basin, edited by: Nio, S. D., Shuttenhelm, R. T. E., and van Weering, T. C. E., Special Publication International Association of Sedimentologists, 5, 385396, 1981.

Myrow, P. and Southard, J. B.: Tempestite Deposition, J. Sediment. Res., 66(5), 875-887, 1996.

Niedoroda, A. W., Swift, D. J. P., and Thorne, J. A.: Modelling shelf storm beds: control of bed thickness and bedding sequence, in: Shelf sandstone, shelf depositional sequence and petroleum accumulation: a symposium, SEPM, Tulsa, Oklahoma, 15-39, 1989.

Putrevu, U. and Svendsen, I. A.: Three-dimensional dispersion of momentum in wave-induced nearshore currents, Eur. J. Mech B/Fluids, 83-101, 1999.

Raudkivi, A. J.: Loose Boundary Hydraulics, 2nd ed., Pergamon Press, New York, 1976.

Rete Ondametrica Nazionale, RON: http://www.idromare.com, 1989.

Rizzi Zannoni, A.: Atlante marittimo delle Due Sicilie, Officina Topografica del Regno delle Due Sicilie, Biblioteca Nazionale di Napoli, sezione Manoscritti, 1792.

Sagnotti, L., Budillon, F., Dinare‘s-Turell, J., Iorio, M., and Macrý, P.: Evidence for a variable paleomagnetic lock-in depth in the Holocene sequence from the Salerno Gulf (Italy): Implications for "high-resolution" paleomagnetic dating, Geochem. Geophys. Geosyst., 6, Q11013, doi:10.1029/2005GC001043, 2005.

Shapiro, G. I., van der Molen, J., and de Swart, H. E.: The effect of velocity veering on sand transport in a shallow sea, Ocean Dynamics, 54, 415-423, doi:10.1007/s10236-004-0089-4, 2004.

Shields, A.: Application of Similarity Principles and Turbulent Research to Bed-Load Movement, translation of original in German by Ott, W. P. and van Uchelen, J. C., California Institute of Technology, Mitteilungen der Preussischen Versuchsanstalt für Wasserbau und Schiffbau, 1936.

Silenzi, S., Antonioli, F., and Chemello, R.: A new marker for sea surface temperature trend during the last centuries in temperate areas: Vermetid reef, Global and Planetary Change, 40(1-2), 105-114, 2004.

Snedden, J. W. and Nummendal, D.: Origin and geometry of stormdeposited sand beds in modern sediments of the Texas continental shelf, in: Shelf sand and sandstone bodies, edited by: Swift, D. J. P., Oertel, G. F., Tilmann, R. W., and Thorne, J. A., Spec. Publication-International Association of Sedimentologists, vol. 14, Blackwell Scientific, Boston, Ma, 283-308, 1991.

Stuiver, M. and Reimer, P. J.: Extended ${ }^{14} \mathrm{C}$ data base and revised CALIB 3.0 14C Age calibration program, Radiocarbon, 35, 215230, 1993.

Svendsen, I. A. and Putrevu, U.: Nearshore mixing and dispersion, Proc. Roy. Soc. Lond. A, 445, 561-576, 1994.

Violante, C. and Budillon, F.: L'evento eccezionale dell'ottobre 1954 nell'offshore di Salerno: portata solida e trasporto eccezionale di sedimento nelle adiacenti aree marine, in: Il nubifragio dell'ottobre 1954 a Vietri sul Mare, Costa di Amalfi Salerno, edited by: Esposito, E., Porfido, S., and Violante, C., CNR 
GNDCI, Pubbl n. 2870, 58-66, 2004.

Violante, C., D'Argenio, B., and Ferreri, V.: Travertine in the rise and decline of the ancient town of Paestum (2500-1000 y B.P.). A short guide-book, Eurobasin School, Event IX, Naples and Benevento 25 June-6 July 2001.
Wheatcroft, R. A. and Drake, D. E.: Post-depositional alteration and preservation of sedimentary event layers on continental margins, I. The role of episodic sedimentation, Mar. Geol., 199, 123-137, 2003.

Wiberg, P. L., Drake, D. E., Harris, C. K., and Noble, M. A.: The sediment transport environment of the Palos Verdes shelf, Cont. Shelf Res., 22(6-7), 987-1004, 2002. 